\title{
Development of alder carr after the abandonment of wet grasslands during the last 70 years
}

\author{
Jan DoudA ${ }^{1 *}$, Alžběta ČEJKovÁ ${ }^{2}$, Karel DoudA $^{3}$, Jana KochÁNKovÁ ${ }^{1,4}$ \\ ${ }^{1}$ Czech University of Life Sciences Prague, Faculty of Environmental Sciences, Kamýcká 1176, CZ-165 21, Praha 6 - Suchdol, Czech Republic \\ ${ }^{2}$ University of České Budèjovice, Faculty of Science, Branišovská 31, CZ-370 05, České Budèjovice, Czech Republic \\ ${ }^{3}$ T.G. Masaryk Water Research Institute, Podbabská 30, CZ-160 62, Praha 6 - Suchdol, Czech Republic \\ ${ }^{4}$ Silva Tarouca Research Institute for Landscape and Ornamental Gardening, Kuětroré náměsti 391, CZ-252 43 Průhonice, Czech Republic
}

Keywords:

aerial photograph /

Alnus glutinosa (L.) Gaertn. /

dendrochronology /

land abandonment /

secondary succession /

wetland

(Received 29 August 2008; accepted 5 April 2009)

Mots-clés :

photographie aérienne /

Alnus glutinosa (L.) Gaertn. /

dendrochronologie /

abandon des terres /

succession secondaire /

zones humides

\begin{abstract}
- The secondary succession of wet grasslands to communities of alder carr dominated by Alnus glutinosa was recorded in different parts of Europe during the 20th century. However, knowledge of such development of alder carr remains insufficient.

- The development of alder carr was reconstructed at five sites in the Czech Republic, using historical aerial photographs and methods of dendrochronology. The aims were to investigate the succession from wet grasslands to alder carr at sites previously intensively managed for agriculture and to find out the role of fluctuations in the groundwater table, caused by artificial drainage channels, in the observed stand dynamics and tree growth.

- The spread of forest (i.e., an increase in forest cover) predominated until the 1970s at all sites. This trend was disrupted by a large-scale dieback of forest stands in four of the five sites after the 1970s, followed by an increase in patch heterogeneity, as indicated by landscape metrics. The radial growth increment in Alnus glutinosa has been affected predominately by local environmental factors, probably including the changing degree of waterlogging. Forest dieback was presumably connected with a lesser extent of drainage channels.

- Our results indicate that observed successional pathways at sites of alder carr were probably caused by local changes in the groundwater table.
\end{abstract}

Résumé - Développement de taillis d'aunes après l'abandon des prairies humides au cours des 70 dernières années.

- La succession secondaire des prairies humides en communautés de taillis d'aunes dominées par $A l$ nus glutinosa a été enregistrée dans différentes parties de l'Europe au cours du $20^{\mathrm{e}}$ siècle. Toutefois, la connaissance du développement de taillis d'aunes reste insuffisante.

- Le développement de taillis d'aunes a été reconstruit dans cinq sites en République Tchèque, à l'aide de photographies aériennes historiques et des méthodologies de la dendrochronologie. Les objectifs étaient d'étudier la succession de prairies humides en taillis d'aunes sur des sites précédemment exploités intensivement par l'agriculture et de découvrir le rôle des fluctuations de la nappe phréatique, causées par le drainage artificiel des canaux, et d'observer la dynamique des peuplements et la croissance des arbres.

- La progression de la forêt (c'est-à-dire, l'augmentation du couvert forestier) a prédominé jusque dans les années 1970 dans tous les sites. Cette tendance a été perturbée par un vaste dépérissement des peuplements forestiers dans quatre des cinq sites après les années 1970, suivie par une augmentation de l'hétérogénéité des bouquets d'arbres, comme indiqué par les paramètres du paysage. L'augmentation de la croissance radiale de Alnus glutinosa a été affectée principalement par les facteurs environnementaux, y compris sans doute l'évolution du degré d'engorgement. Le dépérissement des forêts est probablement lié à une moindre importance des canaux de drainage.

- Nos résultats indiquent que les voies de succession observées sur les sites des taillis d'aunes ont probablement été causées par des changements locaux dans la nappe phréatique.

\footnotetext{
* Corresponding author: douda@fzp.czu.cz
} 


\section{INTRODUCTION}

Alder carrs are forests dominated by black alder (Alnus glutinosa (L.) Gaertn.) that occur in habitats with high, stagnant groundwater levels (Ellenberg, 1996). Due to their specific hydrological regime and their rare occurrence, alder carrs are considered an endangered forest community in Europe (Ellenberg, 1996).

The natural dynamics of alder carr have been discussed in several studies. Both autogenic drivers (Pokorný et al., 2000; Tucker and Fitter, 1981) and various external factors, such as the fluctuation of the groundwater table (Brock et al., 1989; Janssen et al., 1995), the effect of windthrows (Wolf et al., 2004) and the impact of pathogens (Cech, 1998) have been reported as important for the dynamics of alder carr. Moreover, large-scale diebacks (i.e., extensive mortalities of trees or whole stands) are said to be characteristic for alder carr (Pokorný et al., 2000; Tucker and Fitter, 1981). Large-scale diebacks commonly increase the structural diversity of vegetation types in wetland forests (Anderson and Leopold, 2002; Battaglia and Sharitz, 2006). This enhances the heterogeneity of site conditions, such as light and water levels, at the site, important for the diversity of regenerating trees and shrubs (e.g., Battaglia and Sharitz, 2006; Jones and Sharitz, 1998).

Many papers dealing with the dynamics of forest communities have shown that historical human management practices have influenced present forest dynamics (e.g., Foster et al., 1992; Kirby and Watkins, 1997). Brock et al. (1989) and Stančík (1999) discussed the influence of groundwater level increase on alder carr dynamics as a result of the silting of unused drainage channels. Nevertheless, the extent of this impact on vegetation dynamics of alder carr remains unclear.

The alder carrs represent communities whose structure and development have been highly influenced by human activity for a long time. In the past, people drained sites of alder carr (Döring-Mederake, 1990; Ellenberg, 1996) and used them as coppice forests or changed them into meadows and pastures (Brown, 1988; Rybníček and Rybnic̀ková, 1974). In the 20th century, a return towards semi-natural communities of alder carr was mentioned in different parts of Europe (Falińska, 1991; Foster et al., 1992; Güsewell and Le Nédic, 2004). However, knowledge about the mechanisms of succession from wet grasslands to alder carr, as well as the factors driving this process, remain largely unexplored. Similarly, secondary succession to wetland forests throughout the world has not been sufficiently investigated (but, Allen, 1997; Battaglia et al., 2002; DeSteven and Sharitz, 1997; Warren et al., 2004).

The principal aims of our research were (1) to investigate the secondary succession from wet grasslands to alder carr at sites previously intensively managed for agriculture (i.e., wet meadows and reeds) and (2) to find out the role of fluctuations in the groundwater table, caused by artificial drainage channels, in the observed stand development. We had the following specific research questions: what were the directions of secondary succession after the abandonment of wet grasslands? What is the role played by environmental factors, and specifically by changes in the groundwater table, in the observed successional pathways and tree growth?
We postulated the following four hypotheses to explore our aims: (H1) forest cover will increase during succession due to the spread of Alnus glutinosa at the sites; $(\mathrm{H} 2)$ whereas diversity of vegetation cover types will decrease, patch aggregation of particular vegetation types will increase during the course of succession; (H3) the extent of artificial drainage channels on abandoned grasslands will decrease over time due to silting and, thus, the magnitude and direction of succession (see H1, $\mathrm{H} 2$ ) will be modified, and (H4) as to whether local conditions will be altered during succession, the change will be generally reflected by temporal instability of the climate-growth relationship (Biondi, 1997).

\section{MATERIALS AND METHODS}

Research on dynamic systems with short-lived tree species such as Alnus glutinosa is possible with the help of aerial photographs. In the Czech Republic, these have enabled us to understand how vegetation has developed at the selected sites since the 1930s (Škapec and Fišerová, 1999). The radial growth of trees responds very dynamically to changes in waterlogging (Denneler et al., 2008; Lageard and Drew, 2008). For that reason, radial increments are considered to be good indicators of disturbances of the A. glutinosa stands in individual years and, simultaneously, indirect indicators of environmental changes (Laganis et al., 2008).

\subsection{Study sites}

The five largest sites of alder carr (over 9 ha; Tab. I) in the Czech Republic fully satisfying the following criteria were selected. We selected: (1) sites dominated by Alnus glutinosa in forest stands, (2) sites with an expected spontaneous development of alder carr during the 20th century upon abandonment of wet grasslands - four of the five sites are national level nature protection areas established for the protection of alder carr (i.e., nature reserves and national nature reserves) and (3) sites having no obvious sign of recent management activities. All sites are situated in the vicinity of medieval fishponds, which is a result of the fact that alder carrs occur most commonly near these fishponds in the Czech Republic (Douda, 2008). Hydrological conditions and especially groundwater levels at the sites may thus be influenced by fishpond management techniques such as the discharging of water or the regulation of water in the fishponds.

Non-forest communities (i.e., wet grasslands and bushes) were included in the five studied sites, in addition to forest stands, since alder carr alternated with non-forest communities during the study time span. Borders of certain study sites were established so as to comprise all stands dominated by A. glutinosa as well as the grasslands in their surroundings.

A preliminary analysis of historical military maps of the 1st, 2nd and 3rd Austrian Monarchy Military Surveys (i.e., 1764-1768, 18361852 and 1877-1880, respectively) on scales of 1:25000 or 1:28 800 (http://oldmaps.geolab.cz) showed that managed grasslands covered a large part of the studied sites in the 18th and 19th centuries. During this period, the proportion of forest was or became smaller than that of the managed grasslands at all sites, as indicated by the historical maps. These grasslands were drained by artificial drainage systems (open v-shape ditches) that regulated the groundwater table (B. Kloubec, pers. comm.). All ditches were approximately $1-1.5 \mathrm{~m}$ 
Table I. Studied sites.

\begin{tabular}{lcccc}
\hline Site & Latitude (WGS 84) & Longitude (WGS 84) & Study area (ha) & Aerial photographs \\
\hline 1. Stvolínky & $50^{\circ} 37^{\prime} 57.3^{\prime \prime} \mathrm{N}$ & $14^{\circ} 26^{\prime} 19.8^{\prime \prime} \mathrm{E}$ & 14.2 & $1938,1972,2001$ \\
2. Bř́ehynè & $50^{\circ} 34^{\prime} 24.5^{\prime \prime} \mathrm{N}$ & $14^{\circ} 41^{\prime} 38.7^{\prime \prime} \mathrm{E}$ & 9.5 & $1938,1971,2002$ \\
3. Přeseka & $49^{\circ} 02^{\prime} 48.6^{\prime \prime} \mathrm{N}$ & $14^{\circ} 44^{\prime} 22.9^{\prime \prime} \mathrm{E}$ & 9.0 & $1949,1970,2002$ \\
4. Nová řeka & $48^{\circ} 59^{\prime} 49.3^{\prime \prime} \mathrm{N}$ & $14^{\circ} 51^{\prime} 51.1^{\prime \prime} \mathrm{E}$ & 52.7 & $1949,1974,1991$ \\
5. Vrbenské rybníky & $49^{\circ} 00^{\prime} 16.9^{\prime \prime} \mathrm{N}$ & $14^{\circ} 25^{\prime} 52.1^{\prime \prime} \mathrm{E}$ & 76.7 & $1952,1974,1995$ \\
\hline
\end{tabular}

wide (top width) and $1 \mathrm{~m}$ deep (pers. observation). These managed grasslands were abandoned in the first half of the 20th century and were overgrown with forest via secondary succession at all sites.

All study sites can be considered homogeneous in terms of general abiotic conditions. The geological basement of the sites is formed by sedimentary bedrocks of different ages. Soils are classified as Dystric and Eutric Histosols (nomenclature follows Deckers et al., 1998). The average annual precipitation ranges from 550 to $650 \mathrm{~mm}$, the average yearly temperature is $7-8{ }^{\circ} \mathrm{C}$, and the average monthly temperature is approximately $-2{ }^{\circ} \mathrm{C}$ in January and $17{ }^{\circ} \mathrm{C}$ in July (Tolasz et al., 2007). All sites are strongly waterlogged. Groundwater level is relatively stable and the sites are not periodically flooded. The vegetation cover of the sites can be assigned to different vegetation types. From a phytosociological point of view, the alder carrs belong to the alliance Alnion glutinosae Malcuit 1929, the shrub vegetation belongs to Salicion cinereae Müller et Görs ex Passarge 1961 and the sedge and reed vegetation to various units of the order Phragmitetalia Koch 1926. Current remnants of wet meadows may be assigned to the alliance Calthion Tüxen 1937. Alnus glutinosa (L.) Gaertn. and Salix cinerea $\mathrm{L}$. are the most common tree and shrub, respectively. Other trees and shrubs such as Pinus sylvestris L. and Frangula alnus Mill. occur rarely.

\subsection{Aerial photographs}

Panchromatic aerial photographs of all study sites (cartographic scale 1:5000) taken from three time periods (Period 1: 19381952, Period 2: 1970-1974 and Period 3: 1991-2002) were scanned (600 DPI, TIFF format, pixel size $31-56 \mathrm{~cm}$ ) (Tab. I). The spatial resolution of the aerial photographs enabled us to identify shrubs, trees and their canopy coverage. We georeferenced the scanned photographs in ArcGIS 9.1 using a colour orthophotomap from 2004-2006 (pixel size $100 \mathrm{~cm}$ ) taken from the geoportal of Cenia, governed by the Ministry of the Environment of the Czech Republic (http://geoportal.cenia.cz). Aerial photos were geometrically rectified to a set of control points (over 10 points per site were used). To maximise the accuracy and precision of map overlays, we used control points such as roads, buildings and dams (root mean squared errors for entire images were $7 \mathrm{~m}$ or less). Errors due to distortion are considered to be minor because the relief is relatively flat. In order to analyse changes in the vegetation cover, each study site was subdivided in ArcGIS 9.1 using a grid with a cell size of $20 \times 20 \mathrm{~m}$. This cell size corresponds to those used in the studies that successfully identified forest dynamics using aerial photographs at sites of similar size (i.e., 14 to 76 ha) (Kennedy and Spies, 2004; Park et al., 2005). We visually identified the vegetation cover within each cell and for each period as one of the following four vegetation cover types (VCTs): I. Non-forest (absence of bushes and fully-grown trees); II. Nonforest/forest (alternation of non-forest patches with bushes and trees, with a maximum of $70 \%$ area coverage by canopies of trees); III. For- est (minimum $70 \%$ area coverage by canopies of trees and maximum $30 \%$ area coverage by dead trees); IV. Forest dieback (minimum 30\% area coverage by dead trees). In total, 354, 238, 226, 1318 and 1918 cells were evaluated at Sites 1, 2, 3, 4 and 5, respectively.

At all five sites, reconnaissance surveys were carried out in 2004 to identify the relationship between VCTs and the aerial photographs of the last period. In total, ninety-four cells were chosen by stratified random sampling across the sites in dependence on site area and VCTs, and the respective VCT of each cell was checked with field observations. The overall accuracy (Congalton, 1991) of correspondence between the VCTs recorded by field observation and aerial photographs was $94.7 \%$. Producer's and user's accuracy (Congalton, 1991) were higher than $85 \%$, with the exception of user's accuracy for forest dieback VCT (76.5\%). We attribute the lower accuracy in the case of forest dieback to the time lag between the last aerial photographs and the year of field observation at some sites (up to 13 years). The transition time of forest stands to forest dieback may be short due to the fast dieback of trees (Pickett and Cadenasso, 2005).

We identified the extent and direction of vegetation changes using transition matrices that express the probability of each class becoming any other class or remaining the same between two discrete time periods (Gergel and Turner, 2002). Data on changes in vegetation cover over time were obtained by comparing the chronologically ordered VCTs of each cell. The probability of vegetation transition was calculated using Dinamica EGO (Soares-Filho et al., 2002). A log likelihood ratio test ( $G$-test) with Williams correction was performed to test the significance of changes in vegetation cover and vegetation transition rates between the time periods (Alados et al., 2004) using R Software (R Development Core Team, 2007).

Landscape metrics were used for the description of structural changes in vegetation cover (Park et al., 2004). The VCT cover of the study sites, based on a $20 \times 20 \mathrm{~m}$ grid, was converted to raster files. Values of landscape metrics were calculated based on cell adjacencies using the spatial analysis software FRAGSTATS 3.3 (McGarigal and Marks, 1994). The following metrics were used to describe size, diversity and aggregation of VCT patches (Gergel and Turner, 2002; McGarigal and Marks, 1994): Shannon's evenness index (expresses proportion among particular VCTs, ranging between $0-1$; values close to 1 indicate that the proportions of each VCT are equal, while values close to 0 indicate dominance of one VCT), number of patches (total number of patches), mean patch size (average patch size measured across all VCTs), patch richness (number of different VCTs), percentage of like adjacencies of forest VCT (probability that two adjacent cells belong to forest VCT) and contagion (measures overall degree of clumping in the landscape, ranging from 0-100; a high contagion value indicates generally clumped patterns of VCTs, while values close to 0 indicate a dispersed pattern of VCTs).

The drainage channel systems were clearly visible in the aerial photographs in all three time periods. The extent of the drainage channels could not be identified in the forest VCT because the 


\section{Period 1}

Period 2

Period 3

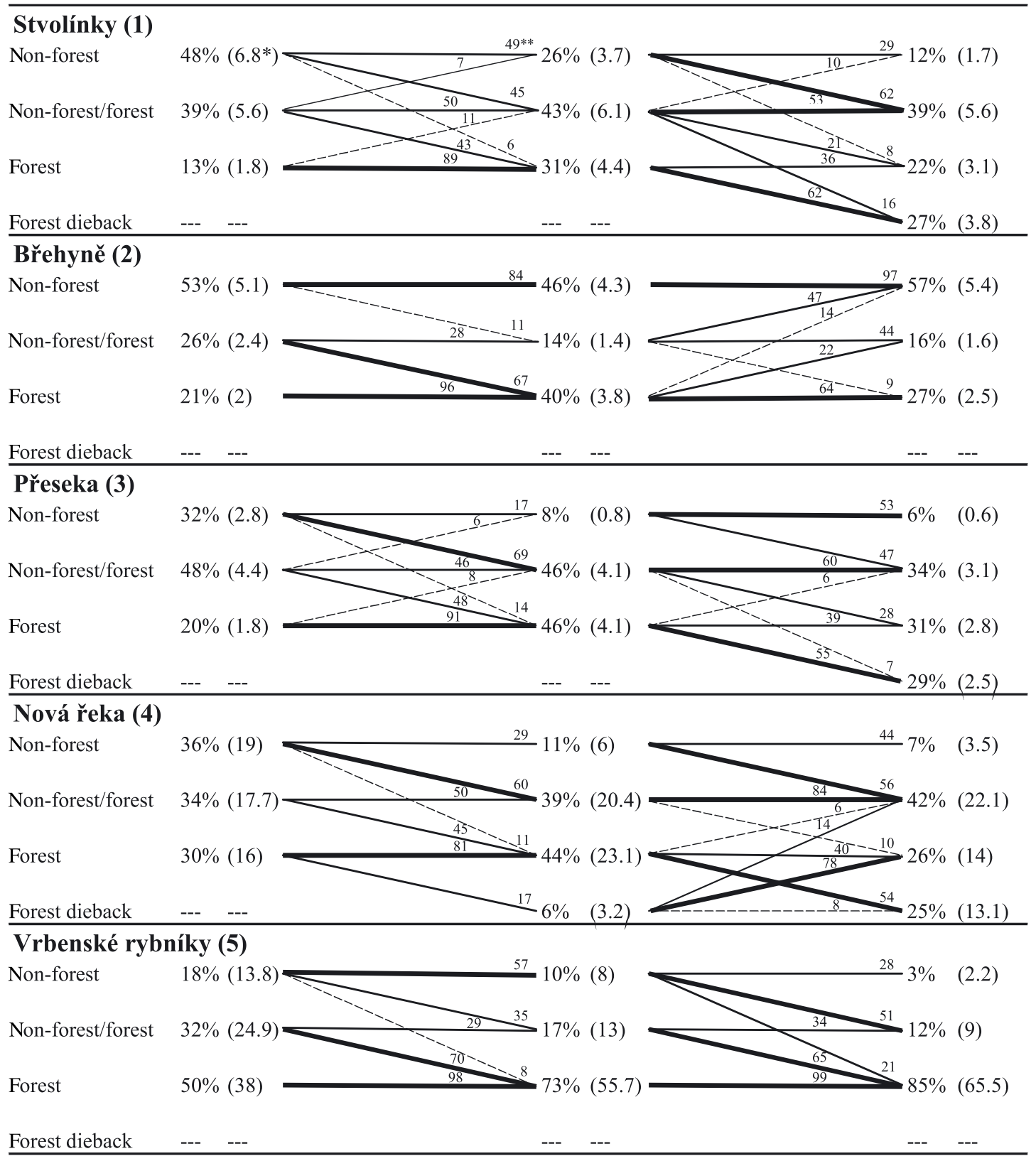

Contribution from previous time layer:

$$
\begin{aligned}
& =\text { minor }(6-15 \%) \\
& =\text { moderate }(16-50 \%) \\
& =\text { major }(>50 \%)
\end{aligned}
$$

Figure 1. Transition matrix of vegetation changes, recorded based on aerial photographs. VCTs are reported in columns $(*$ in ha). The lines represent percentage transitions of VCTs between the two periods $(* *$ in $\%$ ).

drainage channels were not visible in the aerial photographs. Therefore, the extent of the drainage channels was computed as the ratio of the length of the drainage channels $(\mathrm{km})$ to the surface area $\left(\mathrm{km}^{2}\right)$ represented by non-forest or non-forest/forest VCTs in all three time periods. However, we considered it correct to extrapolate the effect of recorded changes to the entire area of the study site, since the non-forest or non-forest/forest VCTs covered large parts of the study sites over the whole studied period $(56 \%, 60 \%, 40 \%, 58 \%$ and $21 \%$ at Sites 1, 2, 3, 4 and 5, respectively). We suppose that the extent of drainage channels is negatively correlated with the groundwater table (e.g., van Linderholm and Leine, 2004; van Seters and Price, 2002). Linderholm and Leine (2004) recorded that the drainage effect of ditches decreased after a decade where the ditches were not maintained. Changes to the extent of drainage channels were tested 
using the $20 \times 20 \mathrm{~m}$ cell grid. The presence or absence of drainage channels was identified in each grid cell representing non-forest or non-forest/forest VCTs in the first and third time periods. A log likelihood ratio ( $G$-test) with Williams correction using R Software was performed to compare the extent of drainage channels (expressed as the presence of drainage channel in a particular cell) between these periods.

\subsection{Dendrochronology}

For the purpose of dendrochronological analyses, three close study sites were chosen (Sites 3,4 and 5) in the same climatic region of South Bohemia. In each site, a mature stand with 30 dominant living trees with no visible signs of damage was selected for sampling. Two increment cores were taken per tree to reveal and eliminate the irregularities and fluctuations of tree growth typical for diffuse-porous tree species such as Alnus glutinosa (Elling, 1966).

Tree-ring widths were measured at an accuracy of $0.01 \mathrm{~mm}$ using a measuring device (TimeTable) and the Past4 software (Knibbe, 2004). The synchronisation of the raw ring-width series was done using Past4 software (Knibbe, 2004) with the help of visual comparisons and well-established statistical parameters: tBP (Baillie and Pilcher, 1973) and GLK\% (Eckstein and Bauch, 1969). Values of tBP greater than 4.0 and GLK\% values greater than $65 \%$ were considered significant. Moreover, the software COFECHA was applied as a validation tool (Holmes, 1983). Due to individual growth characteristics and missing rings, several tree-ring series were excluded from further analyses (about $29 \%$ of the total sample size).

A two-step detrending procedure was done using the ARSTAN software (Cook and Holmes, 1986) to reduce most of the low frequency variability (i.e., age-related trends and non-climatic variations) and to amplify the common signal (Cook and Kairiukstis, 1990). ARSTAN additionally provided a statistical description of the data set by different parameters (e.g., mean sensitivity and signal-tonoise ratio; Tab. III). In the first phase, trends were approximated by a negative exponential function or by a regression line; in the second phase, a cubic smoothing spline with $50 \%$ frequency response of $50 \mathrm{y}$ was used (Cook and Peters, 1981; Lebourgeois et al., 2004). Dimensionless indices were computed as the ratio of the observed ring width to the predicted ring-width value. Autoregressive modelling was performed on each standardised series to remove temporal autocorrelation. Site standard and residual chronologies were calculated from individual indices of each year by means of biweight robust estimation (Cook and Kairiukstis, 1990).

To determine the synchronous extreme growth reaction of trees, we identified pointer years (Lebourgeois, 2007; Schweingruber, 1996) using the method of normalisation in a mowing window (mowing window: $5 \mathrm{y}$, thresholds of index value: $\geq 1$ and $\leq-1$ for positive and negative pointer years, respectively; Cropper, 1979). The pointer year was considered when an extremely narrow or wide tree-ring was detected in at least $40 \%$ of trees per site (Meyer, 1999).

A climate-growth relationship was investigated in the two steps using the software DENDROCLIM2002, that computes the bootstrapped response and correlation functions for single and multiple intervals (Biondi and Waikul, 2004). First, the bootstrapped correlation (CF) and response (RF) function (Cook and Kairiukstis, 1990) were computed for the whole period (1918-2004). Correlation was sought between residual chronologies for Sites 3, 4 and 5 and for monthly climatic data (mean air temperature $\left({ }^{\circ} \mathrm{C}\right)$ and total precipitation $(\mathrm{mm})$ ) from October of the previous year's growth to September of the year of growth. In the second step, we tested temporal changes in the climate-growth relationship, applying moving correlation (MCF) and response (MRF) functions. To provide a sufficient number of degrees of freedom in analyses, the length of the calibration period was $100 \%$ greater than the number of predictors, which was 24 ; thus, only periods $\geq 48$ y were considered. The moving window could not be longer because of an insufficient number of years. The moving functions provided a temporal set of coefficients for each monthly predictor, whereby statistical significance at $P \leq 0.05$ was tested using a bootstrap procedure (Guiot, 1991). Results from MRF were weaker than MCF; therefore, we only used results from MCF for our study.

Meteorological data were obtained from the meteorological station in C̀eské Budéjovice. This station is situated close to the studied sites (21, 28 and $6 \mathrm{~km}$ from Sites 3, 4 and 5, respectively).

\section{RESULTS}

\subsection{Aerial photographs}

Transition matrices (Fig. 1) showed significant differences among the proportions of VCTs during the three time periods $(G$-tests, $P<0.01)$ and among vegetation transition rates $(G$-tests, $P<0.001)$ at all sites. The results of these analyses can be classified into two alternative successional pathways. The first pathway corresponds to four of the five studied sites (Sites 1, 2, 3 and 4). The greatest vegetation change in the period from the 1930s until the 1970s was the increase in forest VCT at the expense of non-forest VCT. At the end of this period, the forest VCT reached its maximum extent at all four sites. Conversely, the period from the 1970s until the present day is characterised by a decrease in forest VCT. Such a decrease was not observed in non-forest/forest VCT at the majority of the sites because shrubs and trees spread simultaneously in marginal parts of the studied sites. The forest VCT was replaced most often by forest dieback or, less commonly, by non-forest/forest and non-forest VCTs. At two sites, non-forest/forest VCT changed to non-forest VCT. Generally, landscape metrics from the 1930s to today (Tab. II) revealed an increase in diversity of vegetation cover, demonstrated by an increase in the number of patches or patch richness. The percentage of like adjacencies of forest VCT increased between Periods 1 and 2 as forest patches expanded, whereas between Periods 2 and 3 it declined as a result of disaggregation of forest VCT due to forest dieback. Values of Shannon's evenness index revealed even distribution of area size among different VCTs rather than the dominance of a single VCT over the whole time of study. Only small increases and a generally low level of patch aggregation of a particular VCT indicated by contagion were recorded over the whole period of the study. At Sites 2, 3 and 4, progress of the contagion index during the entire study time corresponded to the opposite trend of Shannon's evenness index.

The second scenario, observed at Site 5, corresponded to an increase in forest, over the whole study period, without any sign of forest dieback. In comparison with the other sites, landscape metrics revealed a decrease in the diversity of vegetation cover (i.e., a decrease in the number of patches). Continuous overgrowth by forest at the site indicated an increase in the 


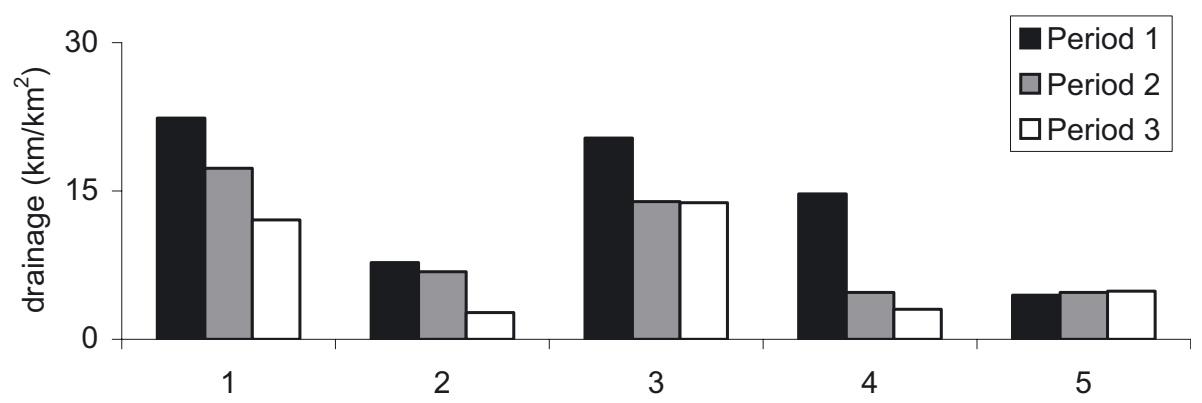

Figure 2. Changes in the extent of drainage channels at Sites 1, 2, 3, 4 and 5 (ratio of the length of drainage channels to the area of the non-forest and non-forest/forest VCTs).

Table II. Structural changes in vegetation cover, measured by landscape metrics; PLADJF (percentage of like adjacencies of forest VCT), SHEI (Shannon's evenness index).

\begin{tabular}{lccccccc}
\hline & Year & $\begin{array}{c}\text { Patch } \\
\text { richness }\end{array}$ & $\begin{array}{c}\text { Number } \\
\text { of } \\
\text { patches }\end{array}$ & $\begin{array}{c}\text { Mean } \\
\text { patch } \\
\text { size (ha) }\end{array}$ & $\begin{array}{c}\text { Contagion } \\
(\%)\end{array}$ & $\begin{array}{c}\text { PLADJF } \\
(\%)\end{array}$ & SHEI \\
\hline Site 1 & 1978 & 3 & 11 & 1.3 & 31.6 & 66.3 & 0.90 \\
& 2001 & 4 & 14 & 1.0 & 28.1 & 79.7 & 0.98 \\
& & & 25 & 0.6 & 26.4 & 58.3 & 0.94 \\
& 1938 & 3 & 7 & 1.4 & 35.3 & 59.8 & 0.92 \\
Site 2 & 1971 & 3 & 4 & 2.4 & 37.9 & 73.2 & 0.91 \\
& 2001 & 3 & 8 & 1.2 & 38.4 & 72.7 & 0.88 \\
& & & & & & & \\
Site 3 & 1949 & 3 & 18 & 0.5 & 24.2 & 46.7 & 0.95 \\
& 2002 & 4 & 19 & 0.5 & 28.6 & 62.0 & 0.84 \\
& & & 17 & 0.5 & 24.9 & 50.8 & 0.91 \\
Site 4 & 1949 & 3 & 37 & 1.4 & 31.7 & 79.1 & 1.00 \\
& 1974 & 4 & 43 & 1.2 & 39.4 & 80.3 & 0.83 \\
& 1991 & 4 & 52 & 1.0 & 35.8 & 65.0 & 0.90 \\
& & & & & & & \\
Site 5 & 1952 & 3 & 57 & 1.3 & 39.4 & 87.7 & 0.93 \\
& 1974 & 3 & 55 & 1.4 & 52.2 & 91.4 & 0.70 \\
& 1995 & 3 & 48 & 1.6 & 66.8 & 93.1 & 0.45 \\
\hline
\end{tabular}

percentage of like adjacencies of forest VCT and a decrease in Shannon's evenness index over the whole study period. A high level of patch aggregation, calculated by contagion, was recorded in the last period.

A comparison of the extent of drainage channels in time (Fig. 2) showed a decreasing trend in Sites $1(G$-test $=16.2$, $P<0.001), 2(G$-test $=4.5, P=0.034), 3(G$-test $=6.2$, $P=0.013)$ and $4(G$-test $=163.5, P<0.001)$. No significant changes were recorded at Site $5(G$-test $=0.1, P=0.824)$.

\subsection{Dendrochronology}

The recorded age of trees (i.e., maximum sample length) was more than $100 \mathrm{y}$ in all sites, but the mean sample length differed among sites (Tab. III). A lower mean sample length (namely in Site 5) was caused by decay. Selected trees showed different levels of radial growth among sites; the mean tree- ring width ranged from $1.7 \mathrm{~mm}$ (Site 5) to $4 \mathrm{~mm}$ (Site 3) (Tab. III).

The values in Table III summarise evidence for the high statistical quality of site chronology obtained. Each site chronology had high values of mean sensitivity, MS, for the total ring (0.38-0.41), relatively low first-order autocorrelation, $\mathrm{AC}(0.52-0.74)$ and a good common signal expressed by the signal-to-noise ratio, SNR (6.44-10.82). This was in agreement with values of population chronology, APC (0.87-0.92), variance in the first eigenvector, VFE (48.20-55.15) and mean correlations among trees, MCT (0.44-0.48). In spite of high statistical quality within site chronologies, chronologies 3,4 and 5 exhibited no cross-coincidence (Tab. III, Fig. 3). A remarkably regular pulse of increment specific to each site was shown in the chronologies at Sites 4 and 5. At site 3, the chronology exhibited a relatively regular pulse only in 1930 1955 (Fig. 3). Calculated pointer years were also site-specific, as indicated in Figure 4.

$\mathrm{CF}$ and RF analyses provided significant but weak correlations between climate and growth for the whole period, 19182004. The negative influence of high July/August precipitation and the positive influence of high August temperatures were recorded at Site 4. The negative/positive influence of high October precipitation/temperature of the previous year was found at Site 5, whereas no climate-growth correlations were determined at Site 3 (Tab. IV).

A climate-growth relationship resulting from the MCF analysis is depicted in Figure 5. The response to August precipitation/temperature at Site 4 was temporally stable. Higher temperatures and lower precipitation resulted in an increase in radial increment that month. Moreover, a positive correlation with January and the previous November's precipitation was recorded in the 1950s-1970s. At Site 5, the influence of the previous October's precipitation/temperature on the growth of tree-ring width was temporally unstable but strong. The radial growth was negatively correlated with October's low precipitation and high temperatures. The negative response to January's high temperature and the positive response to March's high temperature were recorded from the end of the 1980s. At Site 3, a climate-growth relationship was detectable only from the end of the 1970s (positive June/negative July precipitation). Accordingly, $\mathrm{CF}$ and MCF analyses did not detect any strong uniform influence of climate on tree growth at Sites 3, 
Table III. Site chronology information. Statistics were calculated for the period of all standard chronologies, 1918-2004.

\begin{tabular}{lccc}
\hline Chronology & Site 3 & Site 4 & Site 5 \\
\hline Time span & $1902-2005$ & $1880-2005$ & $1902-2004$ \\
Maximum/Minimum sample length (age) & $104 / 52$ & $119 / 43$ & 102 \\
Mean sample length (age) & 76 & $38 / 22$ & 75 \\
Number of cores/trees in chronology & $41 / 25$ & $3.0 / 2.8$ & $49 / 26$ \\
Mean/Median tree-ring width (mm) & $4.0 / 3.6$ & 0.46 & 0.60 \\
Mean sensitivity (relative year-to-year variability) & 0.38 & 10.82 & 0.41 \\
First-order autocorrelation & 0.52 & 48.20 & 0.74 \\
Signal-to-noise ratio & 9.34 & 0.44 & 5.44 \\
Variance in first eigenvector (\%) & 50.25 & 0.92 & 0.15 \\
Mean correlations among trees & 0.46 & 0.90 \\
Agreement with population chronology & 0.90 & 0.87 \\
\hline Correlation/Gleichläufigkeit*(\%) between raw chronologies for period 1918-2004 & Site 4 \\
\hline
\end{tabular}

* According to Eckstein and Bauch (1969).

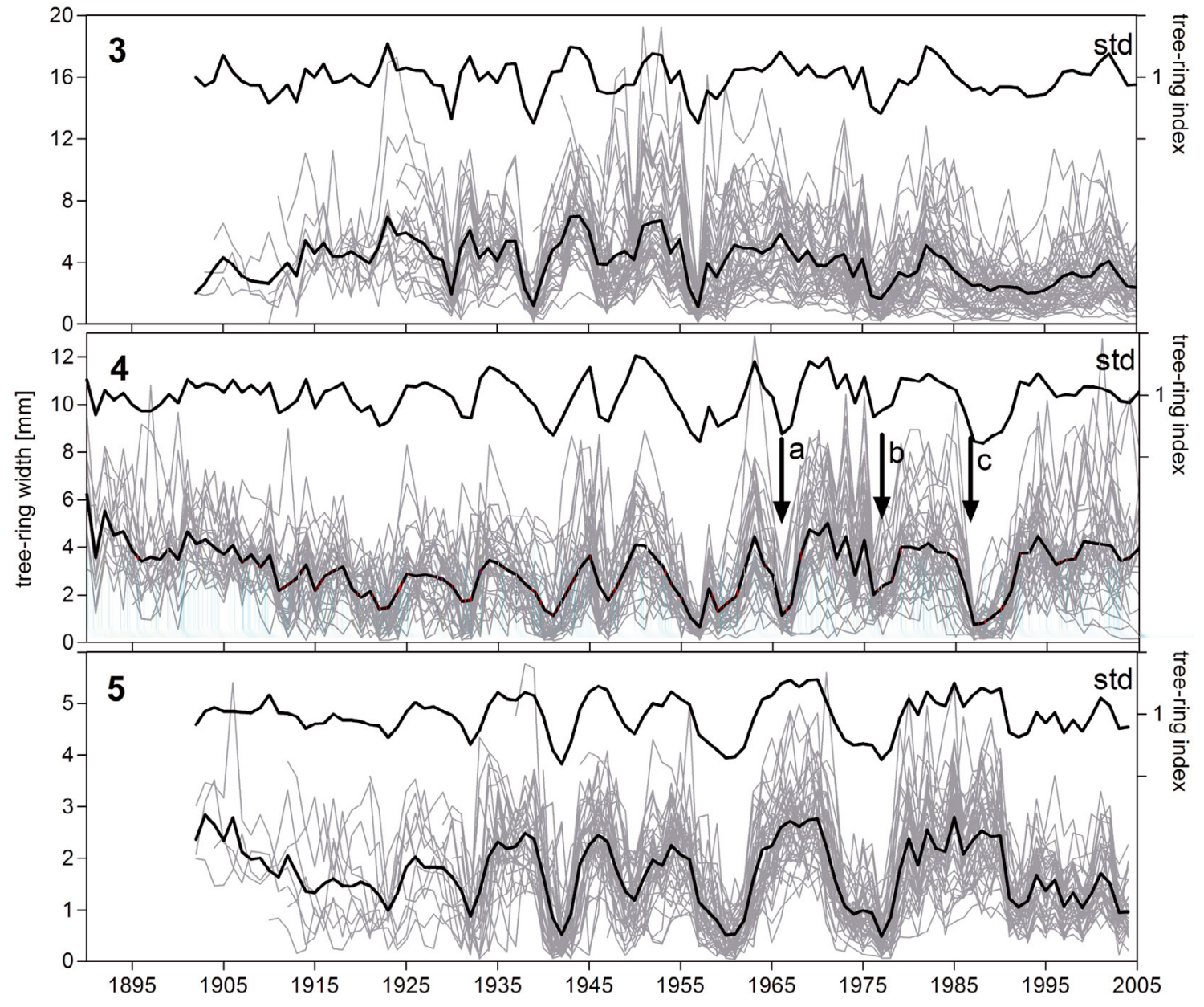

Figure 3. Raw tree-ring series (grey lines), site chronology (bold black line, left $y$-axis) and standard chronology (bold black line - std, right $y$-axis) for Sites 3, 4 and 5; a, b and c - fishpond management (silt removal and reconstruction of a dam in 1965, 1978 and 1984+1985, respectively). 


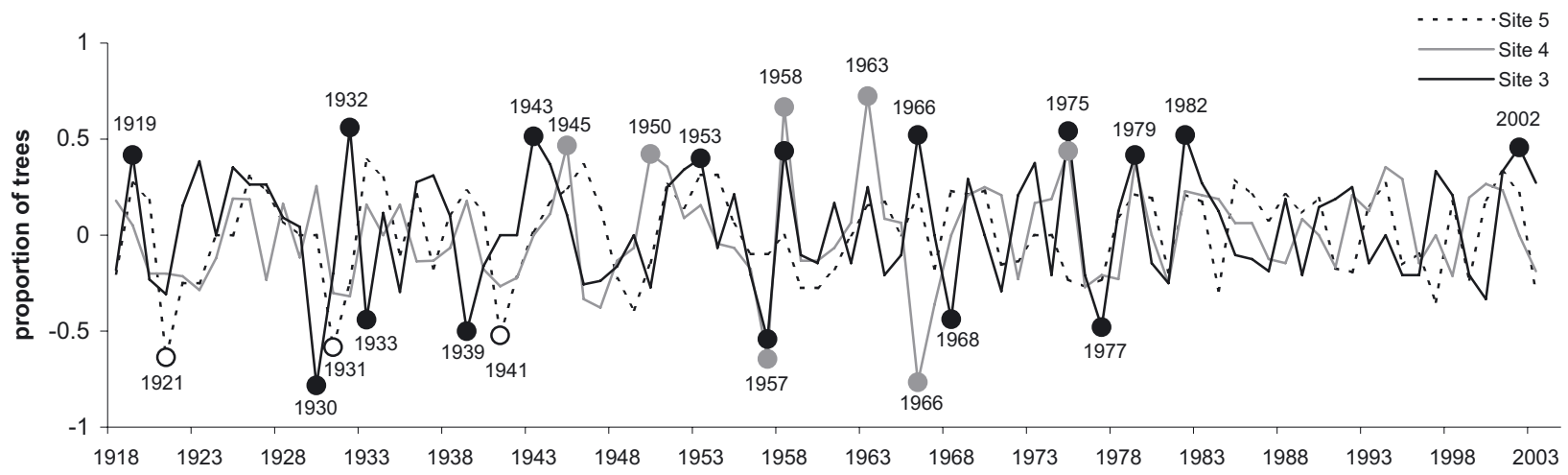

Figure 4. Extreme growth reactions of trees. The $y$-axis characterises the proportion of trees with extremely wide $(+)$ or narrow $(-)$ increments during the same year. Years with synchronous reaction in at least $40 \%$ trees were considered as pointer years (dotted).

Table IV. Climate-growth relationship: significant correlation/response function coefficients $(P<0.05)$ for residual chronologies (Sites 4 and 5), related to mean monthly temperature and precipitation from October of the previous year's growth (p) to September of the year of growth. Statistics were calculated for the same period (1918-2004) for all chronologies.

\begin{tabular}{lccccc}
\hline \multicolumn{5}{c}{ Temperature } & \multicolumn{2}{c}{ Precipitation } & \\
Month & $\mathrm{pX}$ & VIII & $\mathrm{pX}$ & $\mathrm{VII}$ & VIII \\
\hline Site 4 & & 0.319 & & -0.286 & $-0.236 / 0.178$ \\
Site 5 & 0.199 & & $-0.258 /-0.193$ & & \\
\hline
\end{tabular}

4 and 5. The only trend was the common negative sensitivity to high July precipitation from the end of the 1970s (Fig. 5).

\section{DISCUSSION}

\subsection{Vegetation changes and successional trends}

Our research has shown that the studied sites of alder stands that were mainly used as managed grasslands in the second half of the 18th century and in the 19th century were overgrown by forest between the 1930s and the 1970s. This is the result of great changes in agriculture management that took place in the Czech lands. At that time, wetland areas that had previously been cultivated with great effort were left to spontaneous development (Lipský, 1995). On a local scale, Falińska (1991) situates the moment of the formation of young alder woods between 30 and 45 y after abandonment. Similarly, Smit and Olff (1998) recorded that Alnus glutinosa started to be dominant after 20 y of grassland abandonment. This corresponds to the results of our study, in which the first alder stands were recorded after 20 y on previously non-forest area (Fig. 1). Landscape metrics indicated forest and bush expansion, characterised by an increase in stand aggregation at all sites between the 1930s and the 1970s. A previously wellbalanced distribution of particular VCTs changed to a more homogenous vegetation cover dominated by non-forest/forest and forest at most sites. Particular differences in landscape metrics among sites correspond to different starts of succession and times of aerial photograph sensing. Increase in stand aggregation during the expansion of $A$. glutinosa can be facilitated by its limited range of wind dispersal. Wind dispersal and seedling establishment were recorded at a maximal distance of 60-150 $\mathrm{m}$ from the mature alder stand (Cluzeau, 1992; McVean, 1955). In accordance with this finding, Cluzeau (1992) and McVean (1956a) described expansion of A. glutinosa to a eutrophic treeless swamp as a stepwise process determined by the mean distance of seed dispersion and the age at maturity.

Since the 1970s, a diachronic analysis of aerial photographs showed different successional pathways at Sites 1, 2, 3 and 4, on the one hand, and at Site 5, on the other hand. Large parts of alder stands at Sites 1, 2, 3 and 4 have experienced forest dieback, which resulted in an increase in diversity of vegetation cover followed by a decrease in patch aggregation of forest at these sites (Fig. 6a). In contrast, a homogenisation of vegetation cover, connected with an increase in forest patch aggregation and continual increase in forest stands, was observed at Site 5 (Fig. 6b). We explain the different directions of succession by means of local site conditions, and concretely by the groundwater level dynamic. Forest dieback recorded at Sites 1,2, 3 and 4 was related to a decrease in the extent of drainage channels, caused by silting and wearing out of unused ditches. We conclude that these silting processes resulted in a rise in the groundwater table and consequent dieback of the A. glutinosa trees. In accordance with our study, Brock et al. (1989) and Stančík (1999) recorded a similar dieback of alder carr, caused by changes in the soil moisture regime over time, due to regulation of water level by means of drainage channels. Several other studies have reported that a rise in water level was an important reason for A. glutinosa dieback. Janssen et al. (1995) described dieback of forest dominated by A. glutinosa as the consequence of changes in flow-charge river activity. Gorzelak (2000) observed the death of an A. glutinosa stand during a 4-week flood at a site under stagnant water conditions. Similarly, McVean (1956b) mentioned dieback of A. glutinosa 


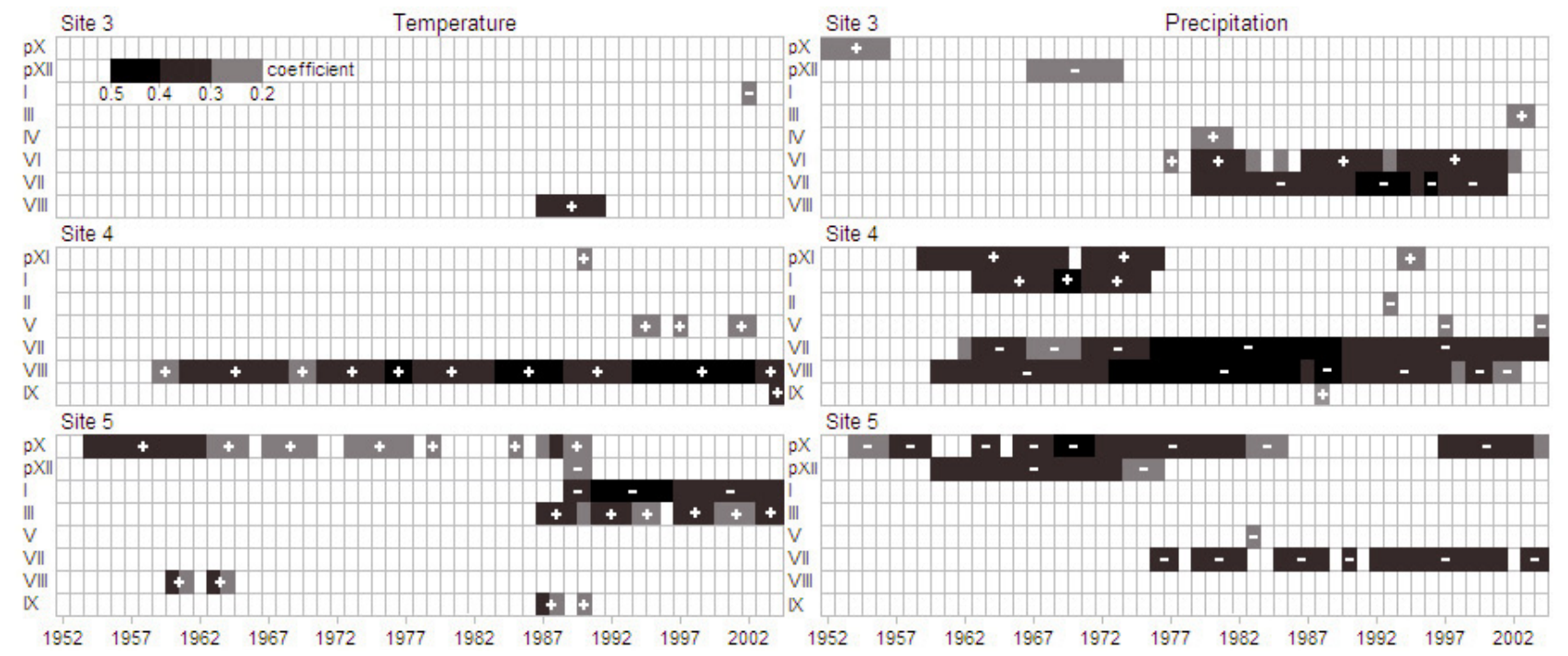

Figure 5. Climate-growth relationship: Moving 48-year correlation functions between mean monthly temperature and precipitation (in previous and given years) and residual chronologies at Sites 3, 4 and 5. Signs indicate positive or negative correlation. Grey, grey/black and black colours express the power of correlation. Only significant month correlations are shown in the diagram $(P<0.05)$; $\mathrm{p}=$ previous year climate variable.

planted in low water table conditions as a consequence of an abnormal increase in the water level.

At Site 5, a different successional pathway, without extensive dieback, can most likely be explained by the maintenance of drainage channels, since no significant changes to the extent of the drainage channels were recorded. Drainage channels have been maintained on site 5 for economic reasons. The locality has served as a pheasantry from the end of the 19th century to the present.

\subsection{Growth responses of Alnus glutinosa to environmental conditions}

Descriptive statistics indicated that the quality of site chronologies of A. glutinosa was comparable with the other chronologies of broad-leaf trees from the temperate zone of Europe (Dittmar et al., 2003; Lebourgeois, 2004; 2005; Rozas, 2005). As these chronologies showed, MS (which expresses the relative variability in growth indices between adjacent rings) usually reaches $0.18-0.39$. High values of MS (usually 0.18-0.39) may suggest a higher sensitivity of A. glutinosa to environmental factors in comparison with other tree species. $\mathrm{AC}$, which indicates a dependence of current growth on the previous year's growth, normally ranges between $0.5-0.79$ and thus corresponds with our results. Similarly, statistics reflecting the common growth variation in the individual ring-width series coincided with normal ranges: SNR 5.1-18, VFE 3058\%, MCAT 0.2-0.64, APC 0.77-0.92 (Dittmar et al., 2003; Lebourgeois, 2004; 2005; Rozas, 2005). We can conclude that tree-ring width of $A$. glutinosa was sufficiently sensitive so as to reflect the signal of exogenous factors; our detected values for A. glutinosa were usually in the middle or higher range of the chronology statistics.
There were no synchronisations of growth variability among the studied sites (Tab. III, Fig. 3) and there were weak similarities among site pointer years (Fig. 4). At the same time, no common coincident responses to climatic factors were recorded for the period 1918-2004 at sites situated in the same region (Sites 3, 4 and 5). Usually, climate was observed as the key unifying factor determining the growth variability within a large geographical range in stands of mesophilous and dry forests (e.g., Baillie, 1995; Peterson and Peterson, 2001). However, several dendroclimatological studies showed a relatively weak relationship between the annual radial growth of trees and the climate in wetlands, characterised by specific and changeable local conditions (Dang and Lieffers, 1989; Linderholm, 1999; Linderholm and Leine, 2004). We suggest that the growth of $A$. glutinosa has been affected mainly by local environmental factors, which may also have modified growth responses to key climatic variables over time. These results correspond to the assertions of Laganis et al. (2008) that radial growth of A. glutinosa seemed to be relatively indifferent to temperature and precipitation fluctuations. Similarly, and in accordance with our results, Laganis et al. (2008) and Levanič (1993) considered local factors, namely, water conditions (i.e., river water level), as the most important factor for the growth of A. glutinosa.

Because all sites of alder stands were situated in the immediate vicinity of fishponds on historically drained wet grasslands, it is probable that development of the alder stands was influenced by both fishpond management (water discharge, silt removal, reconstruction of fishpond dams, etc.) and changes in the extent of artificial drainage channels. These assumptions were supported by the following observations. Firstly, human interventions may explain noticeable irregular depressions in the mean radial increment observed in the mean chronology from Site 4. Silt removal and reconstruction of a 
(a)
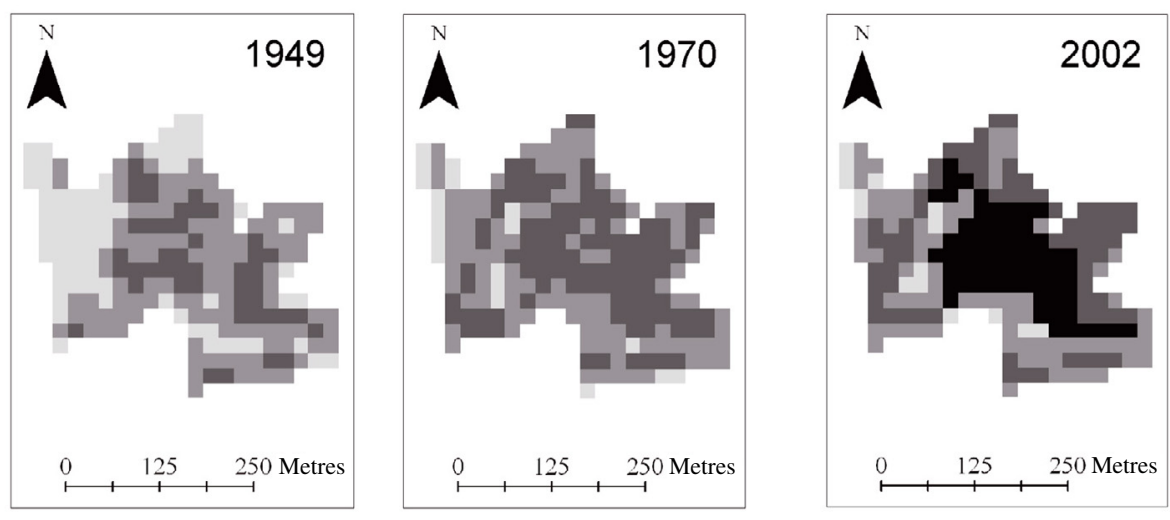

(b)
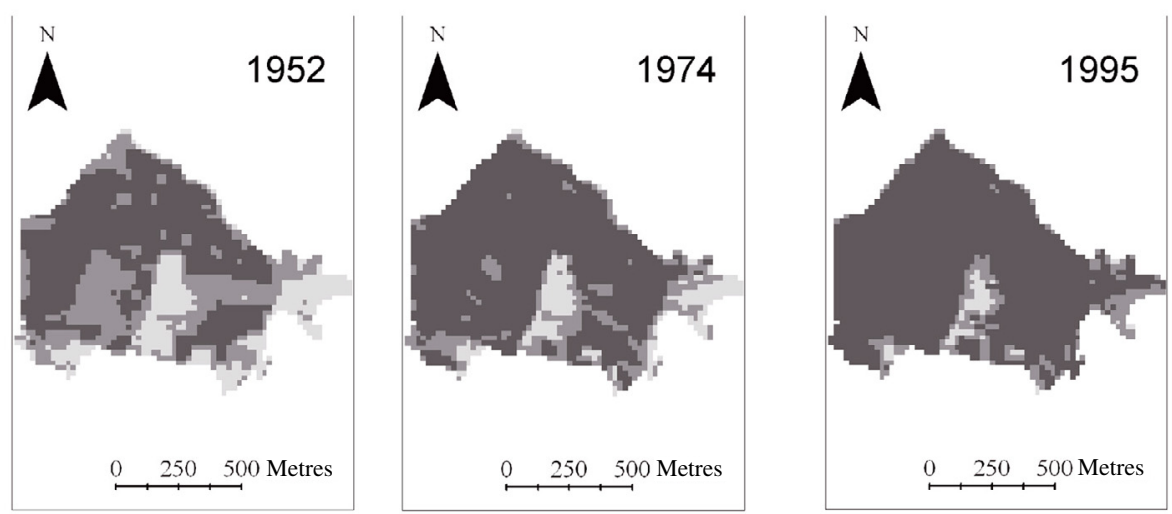

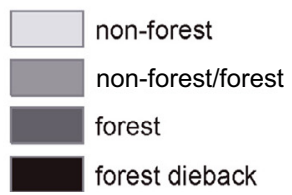

Figure 6. Two different pathways of secondary succession: (a) overgrowth by forest was disrupted by a large-scale dieback of forest after the 1970s (Site 3), (b) continual increase in forest coverage over the whole study period (Site 5).

dam on an adjacent fishpond, which likely increased the level of the groundwater table during the vegetation season, correspond to rapid decreases in radial increment in 1965, 1978 and $1984+1985$, respectively (see Fig. 3). Similar depressions and increases in the series were also observed at Site 5 , which were probably responses to regular maintenance of drainage channels (see Fig. 3). Schweingruber (1996) mentioned an analogous growth response to periodic maintenance of drainage channels. A lowering of the water level due to repeated draining clearly resulted in episodic tree-growth release of Picea abies on a peat bog. Linderholm (1999) discovered that renewal of drainage channels caused an instant increase in annual tree-ring growth of Pinus sylvestris for approximately $10 \mathrm{y}$ on peat bogs in south and central Sweden. Analogously, MacDonald and Yin (1999) recorded growth releases of Larix laricina and Picea mariana after drainage of wetlands. Secondly, a decrease in artificial drainage (which conditioned the rise of the groundwater table at the sites) could explain the recorded temporal instability of the relationship between radial growth and climate at all sites. We believe that the increase in waterlogging probably unified the growth response of A. glutinosa to the climate among the sites (Sites 3, 4 and 5). A change in the growth reaction of trees to the climate due to an increase in water level in the wetlands was also recorded by Linderholm and Leine (2004). Tree growth became less dependent on temperature in their study. We recorded an increase in negative sensitivity to high July precipitation from the end of the 1970s at all sites (Fig. 5). However, at Site 5, this effect was less pronounced. The low sensitivity to high July precipitation at Site 5 could be attributed to the fact that the process of waterlogging was retarded there by partial maintenance of drainage channels, although the site was overgrown by forest. This maintenance work probably also prevented Site 5 from dieback, as was discussed above. 


\subsection{Mechanisms of growth limitation and dieback of Alnus glutinosa}

The water regime of wetlands is a trigger factor for growth limitation of A. glutinosa. An increase in the water table causes oxygen stress (Dittert et al., 2006; Iremonger and Kelly, 1988), a decrease in nitrogen fixation, a reduction in water and nutrient uptake (Iremonger and Kelly, 1988; McVean, 1956b), an increase in levels of toxic minerals in the soils (Lucassen et al., 2006), a decrease in the rate of photosynthesis (Eschenbach and Kappen, 1999), and also root damage (Glenz et al., 2006; McVean, 1956b). All these processes are associated with lower tree-ring increments and could lead to tree dieback.

We propose the following explanation of the mechanism for the dieback of alder carr recorded in this study. First, A. glutinosa spread over wet grasslands with drained soils following the abandonment of management practices. Subsequently, as a result of silting the drainage channels, trees of A. glutinosa were stressed and died due to the increase in groundwater levels. The following physiological and genetic hypotheses were suggested to explain the growth depression of swamp trees in unstable water conditions: (1) Keeland and Sharitz (1997) found that inundation of sites during the vegetation season of three flood-tolerant tree species (Taxodium distichum, Nyssa aquatica and $N$. sylvatica) caused root deterioration, whereas trees growing from juveniles to adults on a permanently waterlogged area developed roots adapted to high water levels; these trees survived inundation during the vegetation season without damage. Other studies have also supported the idea that swamp trees produce roots adapted to waterlogging in soils constantly saturated by water (e.g., Keeley, 1979; Megonigal and Day, 1992); (2) according to Keeley (1979), different levels of tolerance to high water levels were associated with different seedling phenotypes of an opportunistic Nyssa sylvat$i c a$, which occurs at sites along a soil moisture gradient, from non-flooded sites to permanently waterlogged swamps. The phenotype grown at drain sites was weakly tolerant to high water levels and its root system was deteriorated. In contrast, the swamp phenotype was quite tolerant to waterlogged soils.

In our study, A. glutinosa originally recruited on drained soils have died since the 1970 s, probably due to deterioration of non-adapted roots under the long-term, increased water level. An imbalanced root/shoot ratio causes development of internal water and nutrient stress and whole-plant senescence (Tschaplinski and Blake, 1985). Several morphological and anatomical adaptations to waterlogging were described for A. glutinosa: production of adventitious roots, formation of hypertrophied lenticels and aerenchyma formation (e.g., Glenz et al., 2006; McVean, 1956b). Black alder commonly develops a deep-rooting system (McVean, 1956b), which enables the trees to be more drought-resistant. On the other hand, some authors mention the development of a shallow root system in A. glutinosa in waterlogged stands (Dittert et al., 2006; McVean, 1956b). However, it is a question for more detailed research as to the degree these root morphs result from individual plastic responses to an unfavourable environment and to what extent they have some genetic background (see Liepe, 1990).

\section{CONCLUSIONS}

We successfully combined different methods - i.e., historical maps, aerial photographs and dendrochronology - to investigate the development and growth limitation of A. glutinosa-dominated forests at waterlogged sites. The results of this study demonstrated that secondary succession from wetland grasslands to alder carr was influenced by groundwater level. The currently observed dieback of these forests was obviously linked to the malfunction of historical drainage systems. We also established site chronologies of A. glutinosa, which has been a subject of marginal interest to dendrochronologists so far. Studies directed at secondary succession and tree growth limitation in wetlands are needed to understand the processes influencing recent widespread and spontaneous overgrowth of these habitats by A. glutinosa. We formulate the following challenge for subsequent research so as to clear up the objective limitations of our present study: the next studies should be oriented to a comparison of succession pattern and growth limitation of A. glutinosa-dominated forests in various parts of Europe. Direct measurements of water level would provide deeper knowledge about growth limitation. Moreover, other factors that drive secondary succession, such as disturbances, pathogens, herbivory or dispersal limitation should be analysed in those studies. Also, physiological or genetic explanations of dieback of adult trees should be the subject of future research.

Acknowledgements: The authors thank K. Boublík, T. Kyncl, M. Mácová, P. Petrík, J. Sádlo, P. Šamonil and Š. Vojtíšková and the four anonymous reviewers for their critical and helpful comments on this paper, and O. Matèjka and J.A. Marion from AJE for improving our English. The research was funded by grants MoE 0002071101, MSM 6007665801 and MZ P0002707301.

\section{REFERENCES}

Alados C.L., Pueyo Y., Barrantes O., Escós J., Giner L., and Robles A.B., 2004. Variations in landscape patterns and vegetation cover between 1957 and 1994 in a semiarid Mediterranean ecosystem. Landsc. Ecol. 19: $543-559$.

Allen A., 1997. Reforestation of bottomland hardwoods and the issue of woody species diversity. Restor. Ecol. 5:125-134.

Anderson K.L. and Leopold D.J., 2002. The role of canopy gaps in maintaining vascular plant diversity at a forested wetland in New York State. J. Torr. Bot. Soc. 129: 238-250.

Baillie M.G.L., 1995. A slice through time. Dendrochronology and precision dating, Batsford Ltd, London, 176 p.

Baillie M.G.L. and Pilcher J.R., 1973. A simple cross-dating program for tree-ring research. Tree-Ring Bull. 33: 7-14.

Battaglia L.L., Minchin P.R., and Pritchett D.W., 2002. Sixteen years of old-field succession and reestablishment of a bottomland hardwood forest in the lower Mississippi alluvial valley. Wetlands 22: 1-17.

Battaglia L.L. and Sharitz R.R., 2006. Responses of floodplain forest species to spatially condensed gradients: a test of the flood-shade tolerance tradeoff hypothesis. Oecologia 147: 108-118.

Biondi F., 1997. Evolutionary and moving response functions in dendroclimatology. Dendrochronologia 15: 139-150. 
Biondi F. and Waikul K., 2004. DENDROCLIM2002: A C++ program for statistical calibration of climate signals in tree-ring chronologies. Comput. Geosci. 30: 303-311.

Brock T.C.M., Jongerhuis R., van der Molen P.C., and Ran E.T.H., 1989. A comparison of the history and present state of an Alnus glutinosa and Betula pubescens dominated patch of wetland forest in the nature reserve "Het Molenven", The Netherlands. Acta Bot. Neerl. 38: 425-437.

Brown A.G., 1988. The palaeoecology of Alnus (Alder) and the postglacial history of floodplain vegetation. Pollen percentage and influx data from the West Midlands, United Kingdom. New Phytol. 110: 425-436.

Cech T., 1998. Phytophtora decline of alder (Alnus spp.) in Europe. J. Arboric. 24: 339-343.

Cluzeau C., 1992. Dynamique de colonization de l'aune glutineux Alnus glutinosa (L) dans un marais eutrophe de la plaine alluviale du Rhône. Ann. Sci. For. 49: 539-548.

Congalton R.G., 1991. A review of assessing the accuracy of classifications of remotely sensed data. Remote Sens. Environ. 37: 35-46.

Cook E.R. and Holmes R.L., 1986. User manual for program Arstan. In: Holmes R.L., Adams R.K. and Fritts H.C. (Eds), Tree-ring chronologies of western North America: California, eastern Oregon and northern Great Basin, Chronology Series VI, Laboratory of Tree-Ring Research, The university of Arizona, Tuscon, pp. 50-60.

Cook E.R. and Kairiukstis L., 1990. Methods of dendrochronology, Kluwer, Dordrecht, 393 p.

Cook E.R. and Peters K., 1981. The smoothing spline: a new approach to standardizing forest interior tree-ring width series for dendroclimatic studies. Tree-Ring Bull. 41: 45-53.

Cropper J.P., 1979. Tree-ring skeleton plotting by computer. Tree-Ring Bull. 39: 47-60.

Dang Q.L. and Lieffers V.J., 1989. Climate and annual ring growth of black spruce in some Alberta peatlands. Can. J. Bot. 67: 1885-1889.

Deckers J.A., Nachtergaele F.O., and Spaargaren O.C., 1998. World Reference Base for Soil Resources: Introduction, Acco, Leuven and Amersfoort, $165 \mathrm{p}$.

Denneler B., Bergeron Y., Bégin Y., and Asselin H., 2008. Growth responses of riparian Thuja occidentalis to the damming of a large boreal lake. Botany 86: 53-62.

DeSteven D. and Sharitz R.R., 1997. Differential recovery of a deepwater swamp forest across a gradient of disturbance intensity. Wetlands 17: 476-484.

Dittert K., Wötzel J., and Sattelmacher B., 2006. Responses of Alnus glutinosa to anaerobic conditions - mechanisms and rate of oxygen flux into the roots. Plant Biol. 8: 212-223.

Dittmar C., Zech W., and Elling W., 2003. Growth variations of common beech (Fagus sylvatica L.) under different climatic and environmental conditions in Europe - a dendroecological study. For. Ecol. Manage. 173: 63-78.

Douda J., 2008. Formalized classification of the vegetation of alder carr and floodplain forests in the Czech Republic. Preslia 80: 199-224.

Döring-Mederake U., 1990. Alnion forests in Lower Saxony (FRG), their ecological requirements, classification and position within Carici elongatae-Alnetum of Northern Central Europe. Vegetatio 89: $107-119$.

Eckstein D. and Bauch J., 1969. Beitrag zu Rationalisierung eines dendrochronologischen Verfahrens und zu Analyse seiner Aussagesicherheit. Forstwiss. Centbl. 88: 230-250.

Ellenberg H., 1996. Vegetation Mitteleuropas mit den Alpen in ökologischer, dynamischer und historischer Sicht, Ulmer, Stuttgart, 1096 p.
Elling W., 1966. Untersuchungen über das Jahrringverhalten der Schwarzerle. Flora 156: 155-201.

Eschenbach C. and Kappen L., 1999. Leaf water relations of black alder [Alnus glutinosa (L.) Gaertn.] growing at neighbouring sites with different water regime. Trees 14: 28-38.

Falińska K., 1991. Plant demography in vegetation succession, Kluwer Academic Publishers, Dodrecht, 220 p.

Foster D.R., Zebrik T., Schoonmaker P., and Lezberg A., 1992. Postsettlement history of human land-use and vegetation dynamics of a Tsuga canadensis (hemlock) woodlot in central New England. J. Ecol. 80: 773-786.

Gergel S.E. and Turner M.G., 2002. Learning landscape ecology: a practical guide to concepts and techniques, Springer, Berlin, New York, $316 \mathrm{p}$.

Glenz C., Schlaepfer R., Iorgulescu I., and Kienast F., 2006. Flooding tolerance of Central European tree and shrub species. Forest Ecol. Manage. 235: 1-13.

Gorzelak A., 2000. Auswirkungen von Überschwemmungen auf die Flora - am Beispiel des Oderhochwassers 1997. Beiträge zur Forstwirtschaft und Landschaftökologie 34: 8-11.

Guiot J., 1991. The bootstrapped reponse function. Tree-Ring Bull. 51: $39-41$.

Güsewell S. and Le Nédic C., 2004. Effects of winter mowing on vegetation succession in a lakeshore fen. Appl. Veg. Sci. 7: 41-48.

Holmes R.L., 1983. Computer-assisted quality control in tree-ring dating and measurement. Tree-Ring Bull. 43: 69-78.

Iremonger S.F. and Kelly D.L., 1988. The response of four Irish wetland tree species to raise soil water levels. New Phytol. 109: 491-497.

Janssen C.R., Berendsen H.J.A., and van Broekhuizen A.J.D., 1995. Fluvial activity and vegetation development 4000-2000 BP in southwestern Utrecht, The Netherlands. Meded. Rijks Geol. Dienst 52: 357-367.

Jones R.H. and Sharitz R.R., 1998. Survival and growth of woody plant seedlings in the understorey of floodplain forests in South Carolina. J. Ecol. 86: 574-587.

Keeland B.D. and Sharitz R.R., 1997. The effects of water-level fluctuations on weekly tree growth in a southeastern USA swamp. Am. J. Bot. 84: 131-139.

Keeley J.E., 1979. Population differentiation along a flood frequency gradient: physiological adaptations to flooding in Nyssa sylvatica. Ecol. Monogr. 49: 89-108.

Kennedy R.S.H. and Spies T.A., 2004. Forest cover changes in the Oregon Coast Range from 1939 to 1993. For. Ecol. Manage. 200: 129-147.

Kirby K.J. and Watkins Ch., 1998. The ecological history of European forests, $\mathrm{CAB}$ International, Cambridge, $384 \mathrm{p}$.

Knibbe B., 2004. Past4 - Personal Analysis System for Treering Research Version 4, Instruction Manual, SCIEM/Bernhard Knibbe, Wien, $101 \mathrm{p}$.

Laganis J., Pec̀kov A., and Debeljak M., 2008. Modelling radial growth increment of black alder (Alnus glutinosa (L.) Gaertn.) tree. Ecol. Model. 215: 180-189.

Lageard J.G.A. and Drew I.B., 2008. Hydrogeomorphic control on tree growth responses in the Elton area of the Cheshire Saltfield, UK. Geomorphology 95: 158-171.

Lebourgeois F., 2007. Climatic signal in annual growth variation of silver fir (Abies alba Mill.) and spruce (Picea abies Karst.) from the French Permanent Plot Network (RENECOFOR). Ann. For. Sci. 64: 333-343. 
Lebourgeois F., Bréda N., Ulrich E., and Granier A., 2005. Climatetree-growth relationships of European beech (Fagus sylvatica L.) in the French Permanent Plot Network (RENECOFOR). Trees Struct. Funct. 19: 385-401.

Lebourgeois F., Cousseau G., and Ducos Y., 2004. Climate-tree-growth relationships of Quercus petraea Mill. stand in the Forest of Berce ("Futaie des Clos", Sarthe, France). Ann. For. Sci. 61: 361-372.

Levanič T., 1993. Vpliv melioracij na debelinsko rast in prirastek c̀rne jelše, ozkolistnega jesena in doba v Prekmurju. Zbornik gozdarstva in lesarstva 42: 7-65.

Liepe K., 1990. Wachstum und Wurzelentwicklung von 30jährigen Schwarzerlen (Alnus glutinosa [L.] Gaertn.) eines Herkunftsversuches. Allg. Forst- Jagdztg. 161: 149-154.

Linderholm H.W., 1999. Climatic and anthropogenic influences on radial growth of Scots pine at Hanvedsmossen, a raised peat bog, in south central Sweden. Geografiska Annaler 81A(1): 75-86.

Linderholm H.W. and Leine M., 2004. Assessing twentieth century tree-cover changes on a southern Swedish peatland combining dendrochronological and remote sensing methods. Wetlands 24 357-363.

Lipský Z., 1995. Changing face of the Czech rural landscape. Landsc. Urban. Plan. 31: 39-45.

Lucassen E.C.H.E.T, Smolders A.J.P, Boedeltje G., van den Munckhof P.J.J., and Roelofs J.G.M., 2006. Groundwater input affecting plant distribution by controlling ammonium and iron availability. J. Veg. Sci. 17: 425-434.

MacDonald S.E. and Yin F.Y., 1999. Factors influencing size inequality in peatland black spruce and tamarack: Evidence from post-drainage release growth. J. Ecol. 87: 404-412.

McVean D.N., 1955. Ecology of Alnus glutinosa (L.) Gaertn.: II. Seed distribution and germination. J. Ecol. 43: 61-71.

McVean D.N., 1956a. Ecology of Alnus glutinosa (L.) Gaertn.: III. Seedling establishment. J. Ecol. 44: 195-218.

McVean D.N., 1956b. Ecology of Alnus glutinosa (L.) Gaertn.: IV. Root system. J. Ecol. 44: 219-225.

McGarigal K. and Marks B.J., 1994. FRAGSTATS: spatial analysis program for quantifying landscape structure, Version 2.0 [computer program], Oregon State University, Corvallis, 141 p.

Megonigal J.P. and Day Jr. F.P., 1992. Effects of flooding on root and shoot production of bald cypress in large experimental enclosures. Ecol. 73: 1182-1193.

Meyer F.D., 1999. Pointer year analysis in dendroecology: A comparison of methods. Dendrochronologia 16-17: 193-204.

Park A., Kneeshaw D., Bergeron Y., and Leduc A., 2005. Spatial relationships and tree species associations across a 236-year boreal mixedwood chronosequence. Can. J. For. Res. 35: 750-761.

Peterson D.W. and Peterson D.L., 2001. Mountain hemlock growth responds to climatic variability at annual and decadal time scales. Ecol. 82: $3330-3345$.
Pickett S.T.A. and Cadenasso M.L., 2005. Vegetation succession. In: van der Maarel E. (Ed.), Vegetation Ecology, Blackwell Scientific, New York, pp. 178-198.

Pokorný P., Klimešová J., and Klimeš L., 2000. Late Holocene history and vegetation dynamics of a floodplain alder carr: a case study from eastern Bohemia, Czech Republic. Folia Geobot. 35: 43-58.

R Development Core Team, 2007. R: a language and environment for statistical computing. R Foundation for Statistical Computing, Vienna, Austria, $1574 \mathrm{p}$

Rozas V., 2005. Dendrochronology of pedunculate oak (Quercus robur L.) in an old-growth pollarded woodland in northern Spain: establishment patterns and the management history. Ann. For. Sci. 62: 13-22.

Rybníček K. and Rybníčková E., 1974. The origin and development of waterlogged meadows in the central part of the Šumava foothills. Folia Geobot. 9: 45-70.

Schweingruber F.H., 1996. Tree rings and environment. Dendroecology. Swiss Federal Institute for Forest, Snow and Landscape Research, Paul Haupt, Birmensdorf and Berne, 609 p.

Škapec L. and Fišerová D., 1999. Využití historické obrazové a kartografické informace při mapování vegetačního pokryvu/využití půdy v maloplošných chráněných územích, Zpr. Čes. Bot. Společ. 34, Mater. 17: 123-132.

Smit R. and Olff H., 1998. Woody species colonization in relation to habitat productivity. Plant Ecol. 139: 203-209.

Soares-Filho B.S., Pennachin C.L., and Cerqueira G., 2002. Dinamica a stochastic cellular automata model designed to simulate the landscape dynamics in an Amazonian colonization frontier. Ecol. Model. 154: $217-235$

Stančík D., 1999. Zmèny vegetace Břehyňského rybníku v průbèhu posledních 30 let, Zpr. Čes. Bot. Společ. 34, Mater. 17: 107-122.

Tolasz R., Míková T., and Valeriánová A., 2007. Climate atlas of Czechia, ČHMÚ, Praha \& UP, Olomouc, 256 p.

Tschaplinski T.J. and Blake T.J., 1985. Effects of root restriction on growth correlations, water relations and senescence of alder seedlings. Physiol. Plant. 64: 167-176.

Tucker J.J. and Fitter A.H., 1981. Ecological studies at Askham bog nature reserve -2 . The tree population of far wood. The Naturalist 6 : $3-14$.

Van Seters T.E. and Price J.S., 2002. Towards a conceptual model of hydrological change on an abandoned cutover bog, Quebec. Hydrol. Proces. 16: 1965-1981.

Warren II R.J., Rossell I.M., and Moorhead K.K., 2004. Colonization and establishment of red maple (Acer rubrum) in a southern Appalachian wetland. Wetlands 24: 364-374.

Wolf A., Møller P.F., Bradshaw R.H.W., and Bigler J., 2004. Storm damage and long-term mortality in a semi-natural, temperate deciduous forest. For. Ecol. Manage. 188: 197-210. 